\title{
Comparison of Hay and Haylage from Permanent Alpine Meadows in Winter Dairy Cow Diets
}

\author{
G. Borreani, ${ }^{*}$ D. Giaccone, ${ }^{*}$ A. Mimosi, $\dagger$ and E. Tabacco*1 \\ *Dipartimento di Agronomia, Selvicoltura e Gestione del Territorio, Università degli Studi di Torino, 10095 Grugliasco (Torino), Italy \\ †Dipartimento di Scienze Zootecniche, Università degli Studi di Torino, 10095 Grugliasco (Torino), Italy
}

\begin{abstract}
In an Alpine environment, diets based on local forage resources are needed to maintain the link with the territory and confer special characteristics to typical cheeses. Harvesting at a late stage of maturity, high mechanical losses, and frequent rainfall often make the hay that is harvested of a poor quality. The aim of this study was to evaluate the effects of 2 different conservation methods (late hay, LH, vs. early haylage, ES) of natural permanent meadows on milk production in dairy cows, on the chemical and microbiological characteristics of the milk, and on the quality of the cheese over the winter period. Haylage and hay were harvested from the same permanent meadow at the Vittorino Vezzani experimental farm in Sauze d'Oulx $\left(45^{\circ} 02^{\prime} \mathrm{N}\right.$, $6^{\circ} 53^{\prime} \mathrm{E}$, Italy). The ES forage was cut 4 wk earlier than traditional hay, wilted for $30 \mathrm{~h}$, baled at a dry matter (DM) content of about 50\%, wrapped with 6 layers of stretch film, and stored in a protected area. The LH forage was harvested later, when the weather conditions were favorable and, after a 3-d wilting, it was baled and stored indoors. After an 8-mo storage period, the ES had a greater crude protein concentration, organic matter digestibility, and net energy for lactation than LH and a lower neutral detergent fiber and acid detergent fiber. Forty multiparous lactating Aosta Red Pied cows were used in a 19-d period cross-over design to assess the nutritional value of the stored forages. The diets included ES fed ad libitum and $3.5 \mathrm{~kg}$ of DM per cow of concentrate or LH fed ad libitum and $5.1 \mathrm{~kg}$ of DM per cow of concentrate. The dietary DM was $90.1 \%$ for the LH and $59.9 \%$ for the ES. The diets contained 12.6 and $13.0 \%$ crude protein and 48.6 and $48.0 \%$ neutral detergent fiber, for the LH and ES, respectively. The forage intake was greater in the ES treatment than in the LH treatment. The ES treatment produced more milk $(1.7 \mathrm{~kg} / \mathrm{d})$ and more $3.5 \%$ fat-corrected milk (1.5
\end{abstract}

Received February 21, 2007.

Accepted June 30, 2007.

${ }^{1}$ Corresponding author: ernesto.tabacco@unito.it $\mathrm{kg} / \mathrm{d}$ ) than the cows on the LH treatment. The milk fat and protein concentrations were similar in both diets, resulting in a greater protein yield in the ES treatment. The lactose, $\mathrm{pH}$, total bacterial count, and somatic cell count were not different for the treatments. The clostridial spores did not differ between the treatments from preharvest forage to cheese, and no differences were found in terms of cheese quality after maturation. Conserving forage as wrapped bale silage combined with an earlier harvesting date than traditional hay resulted in a suitable method to improve forage quality without increasing the risk of clostridial contamination in the milk and cheeses.

Key words: Alpine environment, wrapped haylage, hay, clostridial spore

\section{INTRODUCTION}

In an Alpine environment, where the winter feeding period can last 7 mo or longer, successful forage conservation is crucial for milk production (Charmley, 2001). Alpine dairy farms involved in the production of typical or protected designation of origin cheeses (Buchin et al., 1999) are generally small in size, have low technology levels, use dual-purpose breeds for milk as well as meat production, have a low milk yield per cow, and have no long-term genetic selection. The milk yield per cow of races bred in an Alpine environment ranges from around 4,000 kg/yr for the Aosta Red Pied to 7,300 kg/ yr for Montbeliarde. Their feeding system is based on extensive grazing in the summer period ( 3 to $4 \mathrm{mo}$ ) and on supplemental confinement feeding over the rest of the year ( 8 to $9 \mathrm{mo}$ ). The summer production is considered to be of better quality, due to the fatty acid composition and flavor components (Mariaca et al., 1997), and offers the consumers a healthy image of the Alpine environment, but it only represents less than $20 \%$ of the annual production. Most cheeses are produced in winter and in the early spring period; thus, important quantities of high-nutritional and hygienic-quality forage need to be conserved. Only diets based on local forage resources can allow a link to be kept with the Alpine territory and can confer special nutritional char- 
acteristics to the typical products (Elgersma et al., 2006). Field-cured hay is currently the main preservation system used in these regions. Hay is usually characterized by low nutritional quality (Hauwuy et al., 1993), due to harvesting at a late stage of maturity, high mechanical losses, and rain that often occurs during haymaking. A recent Italian survey on 7,000 hay samples showed that the quality of mountain hay produced in the first growth cycle is particularly low, with mean values of $63.3 \%$ for NDF (DM basis) and $8.9 \%$ for CP (DM basis; Borreani et al., 2005). As a result, winter milk production needs to be supported with concentrates or maize (Zea mays) silage purchased from outside the Alpine region, and in this way, the basic link between the products and the original land is broken. Since the age of the plants at the time of cutting is the main factor that influences the nutritive value of the forage (Van Soest, 1994), early conservation as hay or silage is necessary to obtain a forage that is suitable to meet the nutritive requirements of dairy cows and to reduce the amount of concentrates in the diet (Jeangros and Thomet, 2004). High precipitation levels during May and June increase the drying times and make it very difficult to achieve the level of dehydration that is necessary for safe storage as dry hay. In this context, wrapped silage can offer many advantages over hay making: large quantities of forage can be conserved in a short time, forage conservation is less weatherdependent, and silage can easily be mechanized. Another advantage is that silage can be harvested with the same equipment that is used for conventional dry hay and requires only the addition of a plastic wrapper (Charmley, 2001). Furthermore, wrapped bale silage, which is a flexible and economical system, has become popular in the lowland farms as an option for storing excellent quality forage, and it can also provide the opportunity of maintaining the high feeding value of young herbage from Alpine meadows (Sicher et al., 1997). The disadvantages that have been identified by producers working with wrapped bale silage include an increased risk of molding and mycotoxin production, an increased risk of listeriosis, clostridial spoilage, and the loss of nutrients due to difficulties in achieving the basic conditions required for stability during the storage of silage (Muck et al., 2003). Specific defects can be observed with low-quality silage (Jonsson, 1991), especially in hard-cooked cheeses where the presence of clostridial spores in silage and in milk can cause serious problems (Colombari et al., 2001), but this is far less frequent for high-quality silage that has been prepared efficiently and with good quality equipment (Vissers et al., 2006).

The main objective of this study was to compare the effects of the conservation method (hay vs. haylage) from natural permanent meadows on the milk production of Aosta Red Pied dairy cows and, subsequently, on the chemical and microbiological characteristics of the milk and the quality of commercial cheese produced during winter in an Alpine environment.

\section{MATERIALS AND METHODS}

The study was conducted at the Stazione Sperimentale Alpina - Vittorino Vezzani experimental farm in Sauze d'Oulx (1,850 m above sea level; $45^{\circ} 02^{\prime} \mathrm{N}, 6^{\circ} 53^{\prime} \mathrm{E}$; mean annual rainfall of $640 \mathrm{~mm}$ with high rainfall levels in May, June, and October; mean annual temperature $4.5^{\circ} \mathrm{C}$, Italy) on a herd of multiparous Aosta Red Pied dairy cows. The cows were fed natural pasture from late May until the end of September, when they were then housed inside and fed a hay-concentratebased diet (DMI $15.5 \pm 0.11 \mathrm{~kg}$ of DM/d) until the beginning of the trial. Parturition of the herd took place on average at the end of November. In the Alpine environments, the breeding commonly emphasizes calving in November to December to have the peak of lactation over the winter-spring period and to avoid fresh cows with high nutritional requirements during the summer grazing season.

\section{Forage Management}

The trial was conducted over the 2003-2004 period. Two treatments were evaluated: i) haylage in wrapped bales (around 50\% DM) or ii) field-dried hay. The hay and haylage were produced on 5.5 ha of native grassland located at 1,500 to $1,600 \mathrm{~m}$ above sea level. An earlier harvesting time for haylage was chosen to improve the quality of the conserved forage. The haylage was harvested on June 19. The hay was harvested later than the haylage in the growing season (July 18), when the weather conditions were favorable for drying hay. The forage was baled (Columbia R10, Wolagri, Suzzara - Mantova, Italy) in 1,200-mm diameter round bales, and the silage bales were individually wrapped (Kverneland Silawrap 7525, Kverneland Group, Naerbo, Norway) using 6 layers of conventional polyethylene stretch film $(500 \mathrm{~mm}$ wide $\times 25 \mu \mathrm{m}$ thick $)$. A total of 26 haylage and 32 hay bales were available for the feeding trial. The hay and haylage bales were stored in a hayloft for 7 to $9 \mathrm{mo}$. The botanical composition of the meadows was determined using clip samples cut from 10 randomly selected $0.1 \times 5 \mathrm{~m}^{2}$ frames. Forage samples were cut at $40-\mathrm{mm}$ stubble height using 100 $\mathrm{mm}$-wide battery-powered grass shears and were handseparated into grass, legume, and other botanical families. Subsamples were dried in an oven at $80^{\circ} \mathrm{C}$ to a constant weight to calculate the ratio among the classes. 
Meteorological data (minimum and maximum daily temperature and daily rainfall) collected for $14 \mathrm{yr}$ (1990 to 2003) at Sauze d'Oulx were utilized to calculate the number of rainy days per month, the total monthly rainfall, and the probability of rain occurrence for a sequence of $2,3,4$, or $5 \mathrm{~d}$ beginning from a rain-free day. A sequence of 2 or 3 rain-free days is representative of the wilting time needed for haylage, whereas a sequence of 4 or 5 rain-free days is representative of the wilting time needed for hay.

\section{Chemical and Microbiological Analyses of Forages}

Forage samples were taken immediately before cutting by clipping herbage from 8 randomly selected 0.1 $\times 10 \mathrm{~m}^{2}$ areas. Forage samples were clipped to a 40 $\mathrm{mm}$ stubble height using 100 -mm-wide battery-powered grass shears and were split into 2 subsamples. One subsample was dried to constant weight at $80^{\circ} \mathrm{C}$ in a forced-draft oven to determine the concentration of DM in each forage. The second subsample was dried to constant weight at $60^{\circ} \mathrm{C}$ in a forced-draft oven for analysis of nutritive value. The silages and hays were sampled during the feeding trial ( 4 times for each experimental period) by coring the bale from its side to a depth of about $450 \mathrm{~mm}$ with a corer (45-mm diameter) immediately before it was fed to the cows. The haylage and hay samples were split into 3 and 2 subsamples, respectively. The first subsample was again dried to constant weight under forced air at $80^{\circ} \mathrm{C}$ to determine the concentration of DM. The second subsample was dried to constant weight under forced air at $60^{\circ} \mathrm{C}$ and then ground thorough a Cyclotec mill (Tecator, Herndon, VA) equipped with a 1-mm screen. The dried samples were analyzed for $\mathrm{CP}(\mathrm{Kjeldahl} \mathrm{N} \times 6.25)$, ash by ignition to $550^{\circ} \mathrm{C}, \mathrm{NDF}, \mathrm{ADF}$ and acid detergent lignin as described by Robertson and Van Soest (1981), ether extract (AOAC, 1990), gross energy (GE) using an adiabatic calorimeter bomb (IKA C7000, Staufen, Germany), and enzymatic OM digestibility (OMD) as described by Aufrère (1982). The GE was determined in wet samples of haylage using polyethylene as a primer in an adiabatic calorimeter bomb. The $\mathrm{NE}_{\mathrm{L}}$ was predicted according to the French system (Andrieu and Demarquilly, 1987). A third wet sample was homogenized and extracted for $4 \mathrm{~min}$ in a Stomacher blender (Seward Ltd., West Sussex, UK) in water or in $0.1 \mathrm{~N}$ $\mathrm{H}_{2} \mathrm{SO}_{4}$ for the haylages. The $\mathrm{pH}$ was determined in the water extracts. The $\mathrm{NH}_{3}-\mathrm{N}$, determined using a specific electrode, was quantified in the water extract. The lactic and monocarboxylic acids (acetic and butyric acids) were determined by HPLC (Canale et al., 1984). The concentrate was sampled on the same days as the forages and analyzed for $\mathrm{DM}$ content, $\mathrm{NDF}, \mathrm{ADF}$, acid detergent lignin, $\mathrm{CP}$, ash, ether extract, GE, and OMD as described previously.

Microbiological analyses of clostridial spores were made following the most probable number technique with lactate-acetate agar (Spoelstra, 1984) after incubation at $37^{\circ} \mathrm{C}$ for $7 \mathrm{~d}$. Duplicate analyses were performed for all the determined parameters. The duplicates were averaged, and the means were considered as observations in the statistical analysis.

\section{Animals and Management}

A herd of 40 dairy Aosta Red Pied cows, maintained in stanchion-type housing and producing a mean annual yield of $3,565 \pm 238 \mathrm{~kg}$ of milk, was selected for the trial. The cows were divided into 2 groups, balanced for parity $(3.9 \pm 0.3)$, BW (506 $\pm 15 \mathrm{~kg})$, stage of lactation (50 \pm 3 DIM), and individual daily milk yield (14.6 \pm $0.44 \mathrm{~kg}$ ) in a 2-period crossover design. Each period lasted $19 \mathrm{~d}$ : $10 \mathrm{~d}$ for adaptation to the ration and $9 \mathrm{~d}$ for data collection (experimental period). All the cows were milked twice daily at 0530 and $1730 \mathrm{~h}$. The feeding trial was conducted during January and February of 2004. Diets included early-cut haylage (ES) fed ad libitum and $3.5 \mathrm{~kg}$ of DM per cow of concentrate or traditional mature hay (LH) fed ad libitum and $5.1 \mathrm{~kg}$ of DM per cow of concentrate. The experimental diets were balanced for energy, protein, and minerals according to NRC (2001) requirements for 506-kg cows with a forage intake predicted as 10.1 and $11.7 \mathrm{~kg}$ of DM/ cow daily, for LH and ES, respectively. The LH hay contained less energy and protein than the more immature ES haylage, and, as a consequence, the cows receiving the LH diet were provided approximately $1.6 \mathrm{~kg}$ more concentrate supplement per day. The concentrate was given at milking and was based on the pretrial milk production. Drinking water was available ad libitum. The hay or haylage was provided at 0730 and 1930 h. The hay and haylage were manually removed from bales, weighed, and offered to each cow for ad libitum intake. Forage refusal weights were recorded twice daily immediately before milking. Orts were collected and analyzed for DM content. Adjustments in offerings, when needed, were made to obtain approximately $10 \%$ refusals. The feed intake was measured daily on individual cows by subtracting the amount of orts from the offered amount of feed.

\section{Milk and Cheese Production and Analyses}

Individual daily milk yields were recorded 8 times (on d 2, 4, 6, and 8 of each experimental period) from both the morning and afternoon milkings. Fat, protein, and lactose contents (Milk-O-Scan 605, Foss Technol- 
ogy, Hillerød, Denmark); total bacterial count; SCC (Fossomatic 360, Foss Technology); coliforms; and clostridial spores according to the methods of the International Dairy Federation (1996) were measured from composite morning and evening milk samples collected on $\mathrm{d} 2,4,6$, and 8 of each experimental period.

The milk obtained in the trials was used for the production of Toma cheese (a raw whole-milk cheese with semisoft curd, which, on average, weighs $4.1 \mathrm{~kg}$ ) following the traditional steps and procedures for the production of this typical Alpine cheese. The bulk milks of the afternoon milking were stored at 8 to $10^{\circ} \mathrm{C}$ for $12 \mathrm{~h}$ and mixed with the respective bulk milks of the morning milking. Eight cheese makings ( 4 for each experimental period) were conducted at the Stazione Sperimentale Alpina - Vittorino Vezzani experimental dairy plant. After $90 \mathrm{~d}$, the ripening cheeses were sampled to count clostridial spores and to evaluate any damage to the cheeses.

\section{Statistical Analysis}

The nutrient compositions of the herbage at cutting and of the haylage and hay used during the feeding trial were analyzed using the ANOVA procedure (Statistical Package for Social Science, v 11.5, SPSS Inc., Chicago, IL) with a significance reported at a 0.05 probability level [dependent variable $=$ type of forage $(1-4)+$ error] . When the calculated values of $\mathrm{F}$ were significant, the Duncan range test $(P<0.05)$ was used to interpret any significant differences among the mean values.

The treatment differences for the milk yield and the DM intake were examined using the following crossover model with a GLM procedure of SPSS (v 11.5, SPSS Inc.):

$$
Y_{i j k}=\mu+P_{i}+C_{j}+T_{k}+e_{i j k}
$$

where $Y_{i j k}=$ dependent variable; $\mu=$ general mean; $P_{i}=$ period effect $(i=1-2) ; C_{j}=$ cow effect $(j=1-20) ; T_{k}=$ type of forage conservation $(k=1-2)$; and $e_{i j k}=$ error. The interactions between period and treatment and period and cow were not significant and were therefore not included in the model.

The chemical-microbiological data of the bulk milk were analyzed using the following model:

$$
Y_{i j}=\mu+P_{i}+T_{j}+e_{i j}
$$

where $Y_{i j}=$ dependent variable; $\mu$ = general mean; $P_{i}=$ period effect $(\mathrm{i}=1-2) ; T_{j}=$ type of forage conservation ( $\mathrm{j}=1-2)$; and $e_{i j}=$ error.

The SCC data were first converted to linear scores $\left[\log _{2}(\right.$ cells $\left./ 12,500)\right]$ because of their nonnormal distribu- tion. Similarly, the microbiological data on the feeds, milk, and cheese were first transformed to base-10 logarithm.

\section{RESULTS AND DISCUSSION}

\section{Typology of Permanent Meadow and Risk of Rain Occurrence}

The botanical composition of the natural meadow was as follows: $35 \%$ of Gramineae, mainly orchardgrass (Dactylis glomerata), red fescue (Festuca rubra), and yellow oatgrass (Trisetum flavescens); 29\% of Fabaceae, mainly red clover (Trifolium pratense), sainfoin (Onobrychis viciifolia), and meadow pea (Lathyrus pratensis); 36\% of other botanical families, mainly common dandelion (Taraxacum officinale), caraway (Carum carvi), introduced sage (Salvia pratensis), tall buttercup (Ranunculus acris), and yellow spring bedstraw (Galium verum). The DM yields were 4.63 and $6.11 \mathrm{Mg}$ of $\mathrm{DM} /$ ha for the ES and $\mathrm{LH}$, respectively.

The average rainfall levels (1990 to 2003 period) in the trial environment (1,600 to 1,800 $\mathrm{m}$ above seal level) during May, June, and July were 76, 101, and $68 \mathrm{~mm}$, respectively, with 11,11 , and 8 rainy days in May, June, and July, respectively (Table 1). The number of rainy days for the studied year were similar to those of the average period. The weather, in Alpine environments in Europe, in May, June, and early July is often rainy with poor drying conditions. These poor weather conditions increase the drying time and make it very difficult to achieve the level of dehydration necessary for safe storage as dry hay without incurring rain damage. The weather conditions and the DM yield of the meadows also can affect wilting time, which for haylage may require less than $24 \mathrm{~h}$ compared with more than $4 \mathrm{~d}$ for hay to reach an optimal moisture content. In our experiment, the forages wilted for haylage reached a DM concentration $>50 \%$ the day after cutting, thereby allowing baling and wrapping within $30 \mathrm{~h}$ after cutting. In contrast, the hay could only be harvested after at least $3 \mathrm{~d}$, even with good and rain-free weather conditions. The risk of rain occurrence increased from $27 \%$ for the 2-day sequence to 46 and $60 \%$ for the 3 - and 4 d sequences (Table 1), respectively, which means that 1 time out of 2, drying forage will incur rain damage if harvesting is delayed beyond $30 \mathrm{~h}$ from cutting.

Weather conditions during the wilting and the harvesting of the forages utilized in the feeding trial were always favorable, and no rain fell during the drying periods for haylage or hay. The expected DM content of $50 \%$ for haylage was reached in $28 \mathrm{~h}$ of wilting. The wilting levels were reached by spreading the forage over the whole cut surface, tedding once and raking before baling. The hay received 2 more tedding treat- 
Table 1. Rainy days (rain $>1 \mathrm{~mm}$ ), total monthly rainfall, and probability of rain occurrence after $2,3,4$, and $5 \mathrm{~d}$ following cutting for May, June, and July in the studied year and for the average period (1990 to 2003)

\begin{tabular}{|c|c|c|c|c|c|c|c|}
\hline \multirow[b]{2}{*}{ Item } & \multirow[b]{2}{*}{ Month } & \multirow{2}{*}{$\begin{array}{l}\text { Rainy } \\
\text { days } \\
\text { (n) }\end{array}$} & \multirow{2}{*}{$\begin{array}{l}\text { Total } \\
\text { monthly } \\
\text { rainfall } \\
(\mathrm{mm})\end{array}$} & \multicolumn{4}{|c|}{$\begin{array}{l}\text { Probability (\%) of } \\
\text { occurrence of rain after }\end{array}$} \\
\hline & & & & $2 \mathrm{~d}$ & $3 \mathrm{~d}$ & $4 \mathrm{~d}$ & $5 \mathrm{~d}$ \\
\hline \multirow[t]{3}{*}{ Studied year (2003) } & May & 11 & 119 & 20 & 40 & 55 & 70 \\
\hline & June & 14 & 74 & 31 & 63 & 88 & 100 \\
\hline & July & 5 & 14 & 15 & 27 & 35 & 42 \\
\hline \multirow[t]{3}{*}{ Average period (1990 to 2003) } & May & 11 & 76 & 26 & 46 & 60 & 70 \\
\hline & June & 11 & 101 & 28 & 46 & 59 & 68 \\
\hline & July & 8 & 68 & 22 & 38 & 50 & 64 \\
\hline
\end{tabular}

ments than the haylage before raking and was harvested after $80 \mathrm{~h}$.

\section{Forage Quality}

The quality of the forages before harvesting and after conservation as hay or haylage is reported in Table 2. The DM content at cutting increased from 20.6 to $33.1 \%$ for the ES and LH, respectively. The preharvesting quality of the forages was greater in the ES than the LH treatment $(P<0.05)$ for $\mathrm{CP}$, fiber content, OMD, and $\mathrm{NE}_{\mathrm{L}}$. The conservation system reduced the forage quality in both the hay and haylage for $\mathrm{CP}$, fiber content, and $\mathrm{OMD}$, but no losses of $\mathrm{NE}_{\mathrm{L}}$ occurred in the haylage system $(P<0.05)$. Due to the particularly good weather conditions, the hay retained as much as $90 \%$ of the preharvest $\mathrm{NE}_{\mathrm{L}}$. The decreases in $\mathrm{CP}$, digestibility, and $\mathrm{NE}_{\mathrm{L}}$ and the increases in fiber components and ash were in the range of values reported for good field- cured hays in Alpine environments (Borreani et al., 2005). The NPN was greater in the conserved forages than in the preharvesting herbage $(P<0.05)$ but never $>33 \%$ of total $\mathrm{N}$, even in the haylage. The GE was almost constant in the preharvesting forage and hay, whereas it was greater in the haylage $(P<0.05)$. These data fall into the range of values reported by McDonald et al. (1991), who stated that the mean GE value of grass silages was about $10 \%$ higher than the usual value of around $18.0 \mathrm{MJ} / \mathrm{kg}$ of $\mathrm{DM}$ for herbage and hay. The haylage had lower poststorage concentrations of NDF and $\mathrm{ADF}$ and greater $\mathrm{CP}, \mathrm{OMD}$, and $\mathrm{NE}_{\mathrm{L}}$ concentrations than hay. Our data are in agreement with McCormick et al. (1998), who indicate that poststorage forage quality is better for haylage than for round-baled hay made from the same crop harvested at more mature growth stages in a lowland environment. The effect of earlier cut on forage quality has long been recognized, and several authors have reported reductions in nutri-

Table 2. Nutrient composition of herbage at cutting and of haylage and hay produced for the feeding trial

\begin{tabular}{|c|c|c|c|c|c|}
\hline \multirow[b]{2}{*}{ Item } & \multicolumn{2}{|c|}{ Fresh herbage at cut } & \multicolumn{2}{|c|}{ Conserved forage } & \multirow[b]{2}{*}{$\mathrm{SE}$} \\
\hline & $\mathrm{I}^{1}$ & II & $\mathrm{LH}$ & $\mathrm{ES}$ & \\
\hline DM, \% & $33.1^{\mathrm{c}}$ & $20.6^{\mathrm{d}}$ & $91.5^{\mathrm{a}}$ & $52.2^{\mathrm{b}}$ & 6.08 \\
\hline Ash, \% of DM & 8.1 & 9.1 & 9.4 & 11.1 & 0.48 \\
\hline $\mathrm{CP}, \%$ of $\mathrm{DM}$ & $8.6^{\mathrm{c}}$ & $12.5^{\mathrm{a}}$ & $8.4^{\mathrm{c}}$ & $10.7^{\mathrm{b}}$ & 0.51 \\
\hline Soluble N, \% of total $\mathrm{N}$ & $26.1^{\mathrm{b}}$ & $29.8^{\mathrm{b}}$ & $31.4^{\mathrm{ab}}$ & $36.6^{\mathrm{a}}$ & 1.35 \\
\hline NPN, \% of total N & $21.6^{\mathrm{b}}$ & $27.6^{\mathrm{ab}}$ & $23.3^{\mathrm{b}}$ & $32.6^{\mathrm{a}}$ & 1.46 \\
\hline Ether extract, \% of DM & $1.6^{\mathrm{b}}$ & $2.4^{\mathrm{a}}$ & $1.7^{\mathrm{b}}$ & $2.1^{\mathrm{a}}$ & 0.09 \\
\hline $\mathrm{NDF}, \%$ of $\mathrm{DM}$ & $64.5^{\mathrm{a}}$ & $52.1^{\mathrm{c}}$ & $64.7^{\mathrm{a}}$ & $57.0^{\mathrm{b}}$ & 1.46 \\
\hline $\mathrm{ADF}, \%$ of $\mathrm{DM}$ & $38.9^{\mathrm{b}}$ & $34.2^{\mathrm{c}}$ & $42.2^{\mathrm{a}}$ & $38.6^{\mathrm{b}}$ & 0.73 \\
\hline Acid detergent lignin, \% of DM & $5.6^{\mathrm{ab}}$ & $5.1^{\mathrm{b}}$ & $6.5^{\mathrm{a}}$ & $5.9^{\mathrm{ab}}$ & 0.16 \\
\hline OM digestibility, \% of OM & $63.2^{\mathrm{b}}$ & $68.7^{\mathrm{a}}$ & $59.4^{\mathrm{c}}$ & $63.6^{\mathrm{b}}$ & 0.85 \\
\hline Gross energy, MJ/kg of DM & $17.7^{\mathrm{b}}$ & $17.6^{\mathrm{b}}$ & $17.6^{\mathrm{b}}$ & $19.5^{\mathrm{a}}$ & 0.27 \\
\hline $\mathrm{NE}_{\mathrm{L}}, \mathrm{Mcal} / \mathrm{kg}$ of $\mathrm{DM}$ & $1.21^{\mathrm{b}}$ & $1.33^{\mathrm{a}}$ & $1.12^{\mathrm{c}}$ & $1.34^{\mathrm{a}}$ & 0.02 \\
\hline $\mathrm{NE}_{\mathrm{L}}, \mathrm{MJ} / \mathrm{kg}$ of $\mathrm{DM}$ & $5.07^{\mathrm{b}}$ & $5.57^{\mathrm{a}}$ & $4.67^{\mathrm{c}}$ & $5.62^{\mathrm{a}}$ & 0.10 \\
\hline $\mathrm{pH}$ & 一 & - & - & 5.13 & \\
\hline Lactic acid, \% of DM & - & - & - & 1.18 & \\
\hline Acetic acid, \% of DM & - & - & - & 0.64 & \\
\hline Butyric acid, \% of DM & - & - & - & 0.08 & \\
\hline $\mathrm{NH}_{3}-\mathrm{N}, \%$ of total $\mathrm{N}$ & - & - & - & 5.06 & \\
\hline
\end{tabular}


tional quality with advancing maturity for different grass and legume forages (Van Soest, 1994). Changes in forage quality during spring growth have also been observed for natural Alpine meadows and pastures (Bovolenta et al., 2002).

The fermentation quality of haylage baled at a DM content of $52 \%$ is reported in Table 2 . The fermentation resulted in a $\mathrm{pH}$ of $5.13 \pm 0.096$, a lactic acid concentration of $1.18 \pm 0.31 \%$ of DM, an acetic acid concentration of $0.64 \pm 0.25 \%$ of the $\mathrm{DM}$, and an $\mathrm{NH}_{3}-\mathrm{N}$ concentration of $5.06 \pm 0.49 \%$ of total N. Butyric acid was detectable, but it was below $0.10 \%$ of DM. Huhnke et al. (1997) reported that 40 to $50 \%$ is the optimum DM content for round bale silages. These levels of DM may be the best compromise among optimizing fermentation, minimizing the risk of heating and mold production, and maximizing DMI by dairy cows. Maximizing DM per bale also is desirable in terms of minimizing consumption of plastic and its associated costs (McCormick et al., 1998), bale weight, and bale number per hectare. In our experiment, the high concentration of DM likely restricted fermentation and resulted in relatively low concentrations of all the fermentation acids and $\mathrm{NH}_{3}$ $\mathrm{N}$. This is consistent with observations reported by Han et al. (2006) for wilted and severely wilted round bale silages. The fermentative haylage profiles obtained in our experiment were similar with those reported by Huhnke et al. (1997) for ryegrass and legume-grass bale silage with similar DM contents. As expected, the butyric acid concentrations were very low in these highDM silages. High butyric acid production is normally associated with undesirable clostridial fermentations that usually occur when DM concentrations are less than 30\% (McDonald et al., 1991).

All the hay and haylage bales were well-preserved at feeding, and no surface or interior mold was observed. The storage losses were similar for the 2 treatments and always below 5\% DM (data not shown). No damage or holes were observed in the plastic covering of the haylage bales. An imperfect seal of the bales leads to aerobic deterioration of the silage, which is caused by the growth of bacteria, yeast, and mold. However, because the haylages were wrapped with 6 layers of plastic film, carefully managed during storage, and fed in winter, aerobic deterioration was not to be expected, especially during the winter period when the ambient air temperatures can be very low. This low risk of deterioration could offer considerable flexibility for feeding and managing haylages in Alpine environments for winter feeding, which is the most critical period for indoor feeding in Alpine farming systems.

\section{Composition of the Diets, Milk Yield, and Quality}

The composition of the diets fed during the trial are reported in Table 3 . The contribution of forage to the
Table 3. Nutrient composition of the experimental diets

\begin{tabular}{lcc}
\hline Item & $\mathrm{LH}^{1}$ & $\mathrm{ES}$ \\
\hline Component (\% of dietary DM) & & \\
$\quad$ Natural Alpine hay & 67.1 & - \\
Natural Alpine haylage & - & 78.2 \\
Concentrate & 32.9 & 21.8 \\
Chemical composition & & \\
DM, \% & 90.1 & 59.9 \\
CP, \% of DM & 12.6 & 13.0 \\
Ash, \% of DM & 9.9 & 11.0 \\
Soluble N, \% of total N & 28.9 & 33.8 \\
NDF, \% of DM & 48.6 & 48.0 \\
ADF, \% of DM & 30.5 & 31.6 \\
Acid detergent lignin, \% of DM & 4.9 & 4.9 \\
OM digestibility, \% of OM & 69.5 & 69.4 \\
NE, Mcal/kg of DM & 1.29 & 1.41 \\
\hline
\end{tabular}

${ }^{1} \mathrm{LH}$ = late hay; $\mathrm{ES}$ = early haylage.

${ }^{2}$ Composition (\%): corn grain, 29.7; soybean meal (44\% CP), 27.0; corn gluten feed, 9.5; wheat bran, 9.5; sunflower meal, 7.8; rice hull, 6.5; calcium carbonate, 2.8; sugarcane molasses, 2.0 ; sodium bicarbonate, 1.0; mineral-vitamin supplement, 1.0 ; vegetable fat, 0.8 ; dicalcium phosphate, 0.8 ; bentonite, 0.8 ; and salt, 0.8 . Supplied the following per kilogram of concentrate: $60,000 \mathrm{IU}$ of vitamin A, 40,000 IU of vitamin $\mathrm{D}_{3}, 50 \mathrm{IU}$ of vitamin $\mathrm{E}, 250 \mathrm{mg}$ of $\mathrm{Zn}, 110 \mathrm{mg}$ of $\mathrm{Mn}, 140$ $\mathrm{mg}$ of $\mathrm{Fe}, 15 \mathrm{mg}$ of $\mathrm{Cu}, 5 \mathrm{mg}$ of I, $0.1 \mathrm{mg}$ of Se, $1.0 \mathrm{mg}$ of $\mathrm{Co}$, and 9 $\mathrm{mg}$ of butylated hydroxytoluene.

DM in the diet was greater for the ES than the LH treatment, due to the better quality of haylage, and this resulted in reduced concentrate inputs for ES than for LH. Concentrate comprised $21.8 \%$ of the ES diet and $32.9 \%$ of the $\mathrm{LH}$ diet. The $\mathrm{NE}_{\mathrm{L}}$ in the total diets averaged 1.41 and $1.29 \mathrm{Mcal} / \mathrm{kg}$ of DM for the ES and LH treatments, respectively, due to the greater energy concentration of the haylage. The total and forage DMI, the milk yield, and milk quality are reported in Table 4. Forage and total DMI were greater $(P<0.001 ; 0.005)$ for the ES diet than for the LH diet. The ES treatment produced more milk $(1.7 \mathrm{~kg} / \mathrm{d})$ and more $3.5 \% \mathrm{FCM}(1.5$ $\mathrm{kg} / \mathrm{d})$ than the cows on the LH treatment $(P<0.001)$. The concentrations of milk fat and protein were similar in both diets, resulting in a greater protein yield in the ES treatment $(P<0.001)$. The lactose, $\mathrm{pH}$, total bacterial count, coliforms and SCC were not different for the treatments.

The feeding trial showed that an earlier cutting date combined with the wilted wrapped bale technique greatly improved the quality of the forages conserved as haylage with a positive influence on the milk and $3.5 \%$ FCM yield $(+11 \%$ and $+8 \%$, respectively), and it permitted a reduction of $31 \%$ of the purchased concentrate compared with hay-based diets. Studies evaluating the effect of forage maturity on milk production have been consistent and have documented clearly that harvesting at an immature stage of growth is critical to maintain high productivity (Harrison et al., 1994) and reduce concentrate supplementation. Cleale and Bull (1986) reported that approximately $1 \%$ more con- 
Table 4. Forage and total DMI, milk yield, and milk composition as influenced by the experimental diets

\begin{tabular}{lcccr}
\hline Item & $\mathrm{LH}^{1}$ & $\mathrm{ES}$ & $\mathrm{SE}$ & $P$-value \\
\hline Forage DMI, kg/d & 10.3 & 12.5 & 0.35 & $<0.001$ \\
Total DMI, kg/d & 15.4 & 16.0 & 0.35 & 0.005 \\
Milk yield, kg/d & 13.2 & 14.9 & 0.93 & $<0.001$ \\
3.5\% FCM, kg/d & 13.5 & 15.0 & 0.34 & $<0.001$ \\
Milk fat, \% & 3.64 & 3.55 & 0.20 & 0.406 \\
Milk fat, kg/d & 0.480 & 0.528 & 0.09 & 0.414 \\
Milk protein, \% & 3.17 & 3.23 & 0.16 & 0.535 \\
Milk protein, kg/d & 0.418 & 0.481 & 0.02 & $<0.001$ \\
Lactose, \% & 4.85 & 4.93 & 0.08 & 0.070 \\
pH & 6.79 & 6.80 & 0.05 & 0.702 \\
Total bacterial count, log/mL & 5.12 & 5.18 & 0.26 & 0.817 \\
Coliforms, log/mL & 1.44 & 1.37 & 0.67 & 0.737 \\
SCC, linear score & 3.10 & 2.46 & 0.74 & 0.307 \\
\hline
\end{tabular}

${ }^{1} \mathrm{LH}=$ late hay; ES = early haylage.

centrate was needed to maintain milk production for each advancing day of forage maturity. In the present experiment, permanent ES meadows were cut $27 \mathrm{~d}$ before LH harvesting (June 18 vs. July 15); as a consequence, the cows on the ES treatment consumed $1.6 \mathrm{~kg}$ of DM/d less concentrate than those receiving hay when they were housed inside ( $165 \mathrm{~d}$ of milking). This means that ES diets could lead to a reduction in the annual purchase of concentrates of about $270 \mathrm{~kg} / \mathrm{cow}$ per year $(1.6 \mathrm{~kg} / \mathrm{d} \times 165 \mathrm{~d}$ of the winter housing period from November through the end of April).

\section{Clostridial Spores and Cheese Quality}

The pre- and poststorage contents of clostridial spores in hay and haylage were low for both treatments (Table 5 ), and the values were in the range of those reported for grass herbage $\left(10^{2}\right.$ spores/g) at harvest over $2 \mathrm{yr}$ (Rammer, 1996) and for well-conserved haylage and hay (Müller, 2005). Our data from hay and haylage at feeding indicated no growth of clostridia during the storage period. This was obtained by making the haylage at a DM content greater than $50 \%$ and then wrapping the bales with 6 layers of plastic to reduce the risks of mechanical damage of the cover. Air penetration can lead to aerobic deterioration, and this can indirectly stimulate the growth of anaerobic clostridia, as was demonstrated by Jonsson (1991).

The clostridial spore content in the raw milk was similar in the 2 treatments and at a level that should be considered to be a contamination threshold above which the risk of butyric fermentation of cheese during ripening can be expected (Stadhousers and Spoelstra, 1990). Vissers et al. (2006) stated that when silage contains on average less than 3 log of clostridial spores/g, a basic pretreatment of udder teats before milking is sufficient to assure a farm tank milk contamination level of below 1,000 spores/L (3.00 log most probable number/L).

A total of 56 and 64 Toma cheeses were produced for the LH and ES, respectively. The average yield efficiency was $11.1 \pm 0.2 \%$ in both treatments (i.e., $9 \mathrm{~kg}$ of milk to obtain $1 \mathrm{~kg}$ of cheese). No differences were found between the treatments, in terms of commercial cheese quality, after 3 mo of maturation. Most of the low-quality cheeses and defects were attributable to coliform contamination and, to a minor extent, to clostridial fermentation, with no differences between the treatments.

\section{CONCLUSIONS}

Wrapped baled silage is a suitable method to improve forage quality in an Alpine environment, because it reduces the wilting time and quality losses. Conserving the forage as wrapped bale silage combined with an earlier harvesting date than traditional hay provided high-quality forage in terms of $\mathrm{CP}$ and $\mathrm{NE}_{\mathrm{L}}$ for the winter feeding of Alpine dairy cows, with a slight reduction in harvested $\mathrm{NE}_{\mathrm{L}}$ per hectare (-9\%) of the permanent meadows. Haylage should not be considered as a replacement of conventional cured hay, and it needs to be coupled with earlier cutting schedules to be effective in improving the quality of conserved forages. The enhanced quality of the conserved forage allowed a greater

Table 5. Clostridial spore contents in forage, milk and cheese, and cheese quality as influenced by the forage conservation method

\begin{tabular}{lcccc}
\hline Item & $\mathrm{LH}^{1}$ & $\mathrm{ES}$ & $\mathrm{SE}$ & $P$-value \\
\hline Clostridial spores & & & & \\
Forage at cutting, log MPN/g & 1.60 & 1.75 & 0.24 & 0.295 \\
Forage at feeding, log MPN/g & 1.89 & 1.72 & & 0.24 \\
Milk, log MPN/L & 3.04 & 3.01 & - \\
Cheese, log MPN/100 g & $<2.00$ & $<2.00$ & - & - \\
Cheese quality & $2 / 56$ & $3 / 64$ & - & - \\
Bad quality batches/total batches & Coliforms & Coliforms & & \\
Type of fermentative defect &
\end{tabular}

${ }^{1} \mathrm{LH}=$ late hay; $\mathrm{ES}=$ early haylage; MPN = most probable number.

${ }^{2}$ Statistical analysis not performed. 
milk yield and a reduction in the winter feeding costs, due to the lower amounts of purchased concentrate necessary to supplement the diet. Wilting to a DM content of around 50\%, wrapping bales in 6 layers of plastic, and carefully managing the bale silages during storage prevented the risk of clostridial or other bacterial contamination in the milk and produced cheeses.

\section{ACKNOWLEDGMENTS}

We would like to thank Vanda Malfatto (Dipartimento di Scienze Zootecniche - University of Turin) for the chemical analysis of the forages, Giuseppe Contestabile and his family (Stazione Sperimentale Alpina-Vittorino Vezzani of Sauze d'Oulx, Italy) for the technical assistance during the feeding trials and cheese-making, and Mauro Gilli and Mario Gilardi (Dipartimento di Agronomia, Selvicoltura e Gestione del Territorio - University of Turin) for the technical assistance during ensiling and hay-making. The work was funded by the Regione Piemonte, Assessorato Qualità, Ambiente e Agricoltura. Project: "Realizzazione del fieno-silo per valorizzare le risorse prative alpine: Utilizzo nella produzione di latte biologico e nella caseificazione di formaggi DOP e di qualità in montagna." All authors contributed equally to the work described in this paper.

\section{REFERENCES}

Andrieu, J., and C. Demarquilly. 1987. Valeur nutritive des fourrages: Tables et prévision. In Alimentation des ruminantes: Rèvision des systèmes et des tables de l'INRA. Bull. Tech. 70:61-73.

AOAC. 1990. Official Methods of Analysis. Vol. I. 15th ed. Assoc. Offic. Anal. Chem., Arlington, VA.

Aufrère, J. 1982. Etude de la prevision de la digestibilité des fourrages par une methode enzymatique. Ann. Zootech. 31:111-130.

Borreani, G., E. Tabacco, P. Blanc, F. Gusmeroli, G. Della Marianna, A. Pecile, A. Kasal, E. Stimpfl, C. Tarello, and D. Arlian. 2005. La qualità del fieno di montagna va migliorata. Inf. Agr. 61:47-52.

Bovolenta, S., E. Saccà, W. Ventura, and E. Piasentier. 2002. Effect of type and level of supplement on performance of dairy cows grazing on alpine pasture. Ital. J. Anim. Sci. 1:255-263.

Buchin, S., B. Martin, D. Dupont, A. Bornard, and C. Achilleos. 1999. Influence of the composition of Alpine highland pasture on the chemical, rheological and sensory properties of cheese. J. Dairy Res. 66:579-588.

Canale, A., M. E. Valente, and A. Ciotti. 1984. Determination of volatile carboxylic acids $\left(\mathrm{C}_{1}-\mathrm{C}_{5}\right)$ and lactic acid in aqueous acid extracts of silage by high performance liquid chromatography. J. Sci. Food Agric. 35:1178-1182.

Charmley, E. 2001. Towards improved silage quality. A review. Can. J. Anim. Sci. 81:157-168.

Cleale, R. M., and L. S. Bull. 1986. Effect of forage maturity on ration digestibility and production by dairy cows. J. Dairy Sci. 69:1587-1594.
Colombari, G., G. Borreani, and G. M. Crovetto. 2001. Effect of ensiling alfalfa at low and high dry matter on production of milk used to make Grana cheese. J. Dairy Sci. 84:2494-2502.

Elgersma, A., S. Tamminga, and G. Ellen. 2006. Modifying milk composition through forage. Anim. Feed Sci. Technol. 131:207225.

Han, K. J., M. Collins, E. S. Vanzant, and C. T. Dougherty. 2006. Characteristics of baled silage made from first and second harvest of wilted and severely wilted forages. Grass Forage Sci. 61:22-31.

Harrison, J. H., R. Blauwiekel, and M. R. Stokes. 1994. Fermentation and utilization of grass silage. J. Dairy Sci. 77:3209-3235.

Hauwuy, A., J. B. Coulon, and J. Paradis. 1993. Effet de la nature du foin des Alpes du Nord sur les performances des vaches laitières. Ann. Zootech. 42:289-298.

Huhnke, R. L., R. E. Muck, and M. E. Payton. 1997. Round bale silage storage losses of ryegrass and legume-grass forages. Appl. Eng. Agric. 13:451-457.

International Dairy Federation. 1996. Federation Internationale de Laiterie, Bruxelles, Belgium.

Jeangros, B., and P. Thomet. 2004. Multi-functionality of grassland system in Switzerland. Pages 11-23 in Proc. 20th Gen. Meet. Eur. Grassl. Fed., Luzern, Switzerland. Br. Grassl. Soc., Reading, UK.

Jonsson, A. 1991. Growth of Clostridium tyrobutyricum during fermentation and aerobic deterioration of grass silage. J. Sci. Food Agric. 54:557-568.

Mariaca, R. G., T. F. H. Berger, R. Gauch, M. I. Imhof, B. Jeangros, and J. O. Bosset. 1997. Occurrence of volatile mono- and sesquiterpenoids in highland and lowland plant species as possible precursors for flavor compounds in milk and dairy products. J. Agric. Food Chem. 45:4423-4434.

McCormick, M. E., G. J. Cuomo, and D. C. Blouin. 1998. Annual ryegrass stored as balage, haylage, or hay for lactating dairy cows. J. Prod. Agric. 11:293-300.

McDonald, P., A. R. Henderson, and S. J. E. Heron. 1991. The Biochemistry of Silage. 2nd ed. Chalcombe Publ., Bucks, UK.

Muck, R. E., L. E. Moser, and R. E. Pitt. 2003. Postharvest factors affecting ensiling. Pages 251-304 in Silage Science and Technology. Vol. 42. D. Buxton, R. Muck, and J. Harrison, ed. Am. Soc. Agron., Crop. Sci. Soc. Am., Soil Sci. Soc. Am., Madison, WI.

Müller, C. E. 2005. Fermentation patterns of small-bale silage and haylage produced as a feed for horses. Grass Forage Sci. 60:109-118

NRC. 2001. Nutrient Requirements of Dairy Cattle. 7th rev. ed. Natl. Acad. Sci., Washington, DC.

Rammer, C. 1996. Quality of grass silage infected with spores of Clostridium tyrobutyricum. Grass Forage Sci. 51:88-95.

Robertson, J. B., and P. J. Van Soest. 1981. The detergent system of analysis and its application to human foods. Pages 123-158 in The Analysis of Dietary Fiber in Food. W. P. T. James and O. Theander, ed. Marcel Dekker, New York, NY.

Sicher, L., G. Gallerani, F. Gasperi, W. Ventura, A. Cavazza, and A. Monetti. 1997. Production of good-quality big bale silage and its effects on a semi-hard cheese. Das Wirtschaftseigene Futter 43:263-280.

Spoelstra, S. F. 1984. Some methods to evaluate the role of clostridia in silage. Intern Rapport IVVO-DLO No. 168. IVVO-DLO, Lelystad, the Netherlands.

Stadhousers, J., and S. F. Spoelstra. 1990. Prevention of the contamination of raw milk by making a good silage. Bull. Int. Dairy Fed. 251:24-31.

Van Soest, P. J. 1994. Nutritional ecology of the ruminant. 2nd ed. Cornell Univ. Press, Ithaca, NY.

Vissers, M. M. M., F. Driehuis, M. C. Te Giffel, P. De Jong, and J. M. G. Lankveld. 2006. Improving farm management by modeling the contamination of farm tank milk with butyric acid bacteria. J. Dairy Sci. 89:850-858. 